DAS28-ESR clinical remission or low activity was achieved, generally from week 16 to 20, although relapses were frequent and all cases need retreatment after 6-9 months. In 4 patients, RTX retreatment dosage was optimized to $1 \mathrm{~g} /$ cycle. The 3 patients with pulmonary involvement showed stabilization (2 cases) or improvement (1) of the lung function (as defined by the American Thoracic Society). In patients with GMN, renal response to RTX treatment was complete in a patient and partial in the other. The patient with ITP entered remission after the first RTX cycle and no more cycles were needed. Response in patients with serositis and lymphadenitis was also complete and maintained. Moreover, the glucocorticoid doses were reduced to less than half of the initial dose in all cases. At the end of the follow-up, 7 out of the 13 patients (54\%) were still being treated with RTX. For the remaining 6 patients, RTX was withdrawn because of primary failure (1), recurrent bacterial infections (2), gestational desire (2) sustained remission (1).

Conclusion: According to our preliminary results, RTX seems to be effective and relatively safe in patients with csDMARDs-resistant active MCTD.

Disclosure of Interests: L Montolio-Chiva: None declared, J. Narváez: None declared, Juanjo J Alegre-Sancho Consultant of: UCB, Roche, Sanofi, Boehringer, Celltrion, Paid instructor for: GSK, Speakers bureau: MSD, GSK, Lilly, Sanofi, Roche, UCB, Actelion, Pfizer, Abbvie, Novartis, J Lluch Pons: None declared, Ana V Orenes Vera: None declared, I Vázquez-Gómez: None declared, Maribel Mora: None declared, Xavier González: None declared, Carla Marco: None declared, Jesús Rodriguez: None declared, Montserrat Romera: None declared, Joan Miquel Nolla: None declared

DOI: 10.1136/annrheumdis-2020-eular.4778

\section{AB0595 EFFECTIVENESS OF TOPICAL SODIUM TIOSULFATE FOR THE TREATMENT OF CALCINOSIS-ASSOCIATED CUTANEOUS ULCERS IN PATIENTS WITH SYSTEMIC SCLEROSIS}

I. Torner Hernández ${ }^{1}$, A. Sendra-García ${ }^{1}$, V. Núñez-Monje ${ }^{1}$, L. Montolio-Chiva $^{1}$, A. V. Orenes Vera ${ }^{1}$, I. Vázquez-Gómez ${ }^{1}$, E. Flores Fernandez ${ }^{1}$, À. MartínezFerrer $^{1}$, E. Valls-Pascual1 ${ }^{1}$, D. Ybáñez-García ${ }^{1}$, J. J. Alegre-Sancho ${ }^{1} .{ }^{1}$ Hospital Universitari Dr Peset, Rheumatology, Valencia, Spain

Background: Treatment of calcinosis associated with systemic sclerosis (SSc) mainly involves the use of systemic therapies, which often have limited efficacy. However, little attention has been paid to local treatment, which is especially useful when associated with skin ulcers.

Objectives: To show our experience with topical sodium thiosulfate (TST) for the treatment of calcinosis-associated cutaneous ulcers in patients with SSc.

Methods: Descriptive analysis of a case series of patients with SSc and calcinosis-associated skin ulcers treated with TST. Wound management procedure: wounds and perilesional skin cleaning and disinfection is performed and, if needed, additional debridement. TST is compounded at $25 \%$ as w/o emulsion, for extensive calcinosis, or as beeler-base or cold-cream ointment, for limited calcinosis. Wounds are then covered with a polymeric foam dressing. This cure in moist healing environment shows some advantages over the dry cure (exudate control without damaging the periulceral skin, protection against contamination, and reduction of the needed cures, healing time and pain).

Results: Nine patients (7 women) with calcinosis-associated skin ulcers and SSc were included: 2 patients with diffuse SSc (DcSSc), 6 with limited SSc (LcSSc) and 1 with overlap syndrome. Median age was 60 years (IQR 20). 6 patients had localized wounds and 3 had extensive involvement and/ or tumoral calcinosis which had been refractory to systemic treatment with diltiazem, colchicine, zoledronate, rituximab, and/or acenocoumarol and had suffered recurrent superinfections. Follow-up results of more than 3 months are available for 8 patients, who have been on TST a median time of 9 months (IQR 8.25). They have shown clinical improvement (disappearing of many calcinosis foci and partial or complete healing of the ulcers together with an improvement in pain, function, quality of life and satisfaction of the patients). Radiological improvement was also observed in 1 case. No TST related adverse effect has been detected, except for slight maceration of the wound edges due to the ointment preparation, which was resolved by protecting these with zinc oxide cream

Conclusion: In our experience, treatment with TST for calcinosis-associated skin ulcers in patients with SSc is an effective, safe and easily implementable therapeutic alternative in clinical practice.

Disclosure of Interests: Inmaculada Torner Hernández: None declared, A Sendra-García: None declared, V Núñez-Monje: None declared, L Montolio-Chiva: None declared, Ana V Orenes Vera: None declared, I VázquezGómez: None declared, Eduardo Flores Fernandez: None declared, À Martínez-Ferrer: None declared, Elia Valls-Pascual Grant/research support from: Roche, Novartis, and AbbVie, Speakers bureau: AbbVie, Lilly, Pfizer,
MSD, Novartis, Janssen, Bristol Myers Squibb, UCB Pharma, D YbáñezGarcía Speakers bureau: Lilly, Roche, Sanofi, Juanjo J Alegre-Sancho Consultant of: UCB, Roche, Sanofi, Boehringer, Celltrion, Paid instructor for: GSK Speakers bureau: MSD, GSK, Lilly, Sanofi, Roche, UCB, Actelion, Pfizer, Abbvie, Novartis

DOI: 10.1136/annrheumdis-2020-eular.2562

\section{\begin{tabular}{|l|l}
\hline AB0596 & PREDICTORS, LONG TERM CLINICAL AND
\end{tabular} TREATMENT OUTCOMES IN SOUTH ASIAN PATIENTS WITH IDIOPATHIC INFLAMMATORY MYOSITIS: A SINGLE CENTER STUDY}

A. Nair ${ }^{1}$, R. Goel ${ }^{1}$, P. Chebbi ${ }^{1}$, A. Mathew ${ }^{1}$, A. Ganapati ${ }^{1}$, G. Rebekah ${ }^{2}$, B. Yadav ${ }^{2}$, J. A. J. Prakash ${ }^{3}$, D. Danda ${ }^{1}$, J. Mathew ${ }^{1} .{ }^{1}$ Christian Medical College Hospital, Clinical Immunology and Rheumatology, Vellore, India; ${ }^{2}$ Christian Medical College, Vellore, Biostatistics, Vellore, India; ${ }^{3}$ Christian Medical College, Vellore, Microbiology, Vellore, India

Background: Idiopathic inflammatory myositis (IIM) are a heterogeneous group of immune-mediated disorders with varied presentations and multiple organ involvement. Data on long term outcome among South Asian patients with IIM is sparse.

Objectives: To study the long term clinical outcome, treatment responses and factors predicting outcome among adult patients with IIM

Methods: Patients diagnosed as 'Idiopathic Inflammatory Myositis' under the department of Clinical Immunology and Rheumatology at CMC, Vellore, India were screened retrospectively. Patients aged 18 years and above, satisfying Bohan and Peter criteria, having follow up of one year or more with atleast two outpatient or inpatient visits between January 2010 and April 2019 were included in this study. Those patients with connective tissue disease associated myositis were not included. Details on muscle weakness, extramuscular involvement, muscle enzymes and treatment administered were recorded at baseline, 3, 6, 12, 18, 24 months and yearly thereafter. After assessing their cumulative response, categorization of patients into complete and partia responders was done. Complete responders were defined as patients with persistent muscle power of more than 4/5 and/or MMT 8 more than 76/80, complete resolution of skin, articular and lung involvement (if any) as well as muscle enzymes less than twice the upper limit of normal without any docu mented flares during the entire follow up period. Patients not satisfying the said criterias were grouped as Partial responders. Disease free survival duration was also analyzed

Results: Out of 310 patients of IIM identified, 187 (60.3\%) patients satisfied the inclusion criteria. Women were 2.2 times more than men and mean age at symptom onset was $35.7 \pm 12.6$ years. Dermatomyositis was the predominant myositis subtype seen. All patients were put on steroids with the mean dose being $45.9 \pm 18.6 \mathrm{mg} /$ day. At baseline, the key immunosuppressants used were methotrexate in $44.9 \%$ and mycophenolate in $37.6 \%$ patients. The median follow up duration was $48(25-80)$ months. An associated malignancy was diagnosed in $3.2 \%$ after a median duration of 24.5 months. Five patients expired after a median duration of 80 months from diagnosis. Normal muscle power was attained in $76.1 \%$ patients and $88.6 \%$ were vocational by the last follow up visit. Steroids were discontinued in $56.7 \%$ patients after a median duration of 24 months $(p=0.0002)$. Discontinuation of the immunosuppressant was feasible in $10.2 \%$ patients after a median duration of 44 months. Assessment of

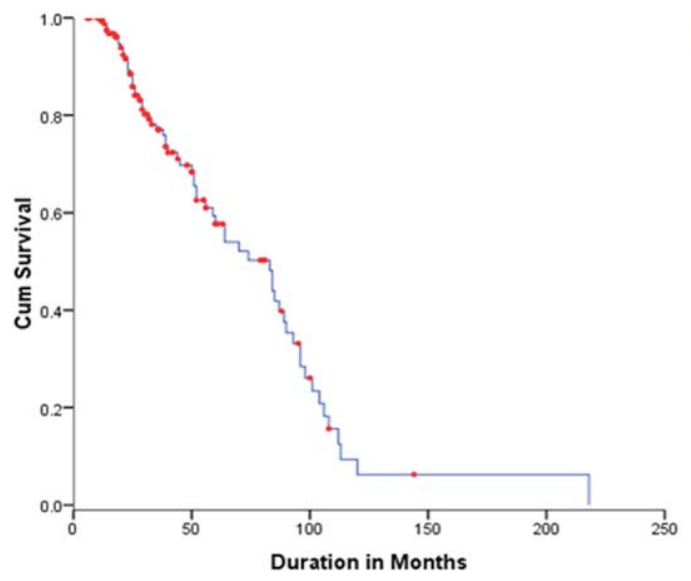

$\neg$ Survival Function Censored

Figure 1. Disease free survival plot of patients with IIM 